This item was submitted to Loughborough's Research Repository by the author.

Items in Figshare are protected by copyright, with all rights reserved, unless otherwise indicated.

\title{
A new mapping of the world for the new millennium
}

PLEASE CITE THE PUBLISHED VERSION

http://dx.doi.org/10.1111/1475-4959.00019

\section{PUBLISHER}

Blackwell Publishing @ The Royal Geographical Society

VERSION

AM (Accepted Manuscript)

\section{LICENCE}

CC BY-NC-ND 4.0

\section{REPOSITORY RECORD}

Taylor, Peter J., Michael Hoyler, David R.F. Walker, and Mark J. Szegner. 2019. "A New Mapping of the World for the New Millennium". figshare. https://hdl.handle.net/2134/13051. 
This item was submitted to Loughborough's Institutional Repository (https://dspace.lboro.ac.uk/) by the author and is made available under the following Creative Commons Licence conditions.

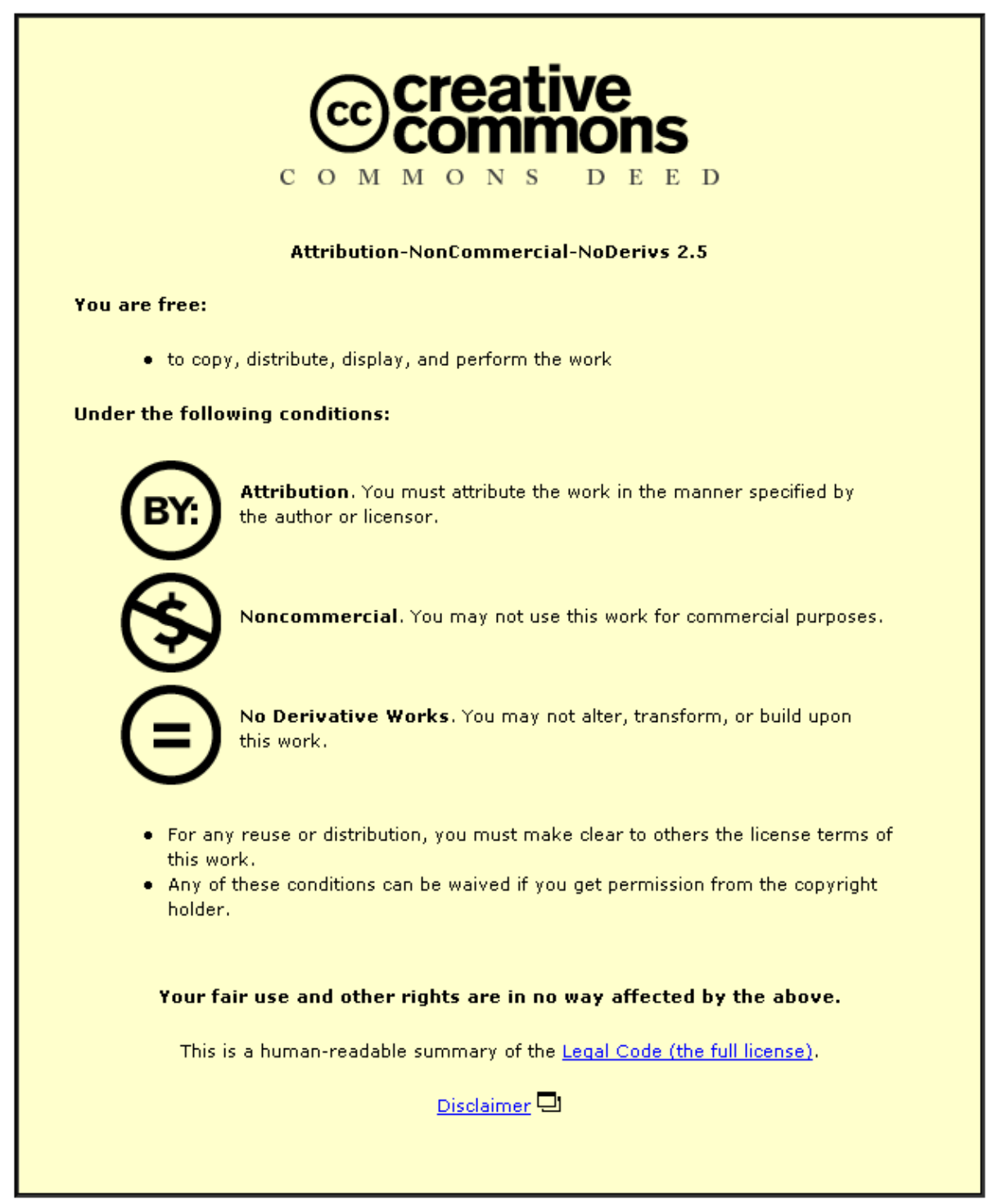

For the full text of this licence, please go to: http://creativecommons.org/licenses/by-nc-nd/2.5/ 


\title{
A new mapping of the world for the new millennium
}

Peter J. Taylor*, Michael Hoyler ${ }^{* *}$, David R.F. Walker* and Mark J. Szegner*

\author{
*Department of Geography \\ Loughborough University, Loughborough \\ LE11 3TU, UK \\ **Geographisches Institut \\ Universität Heidelberg, Berliner Straße 48 \\ 69120 Heidelberg \\ Germany
}




\begin{abstract}
A new mapping of the world derived from connections between cities is presented as a complement to the traditional world map of countries. Under conditions of contemporary globalization world cities have emerged as global service centres. These have been created by the location strategies of leading corporate service firms (e.g. in accountancy) in setting up their global office networks. Data on the offices of 46 global service firms in 55 world cities are used to define service connections between cities. Connections are converted into measures of network proximity and a multidimensional scaling is applied to these 'distances' to create a 'global service space' of cities. This new mapping of the world shows a distinctive centric structure with the major world cities (e.g. London) at the core. Investigation of this general structure reveals more subtle patterns of interacting regional and hierarchical tendencies.
\end{abstract}

Key words: World map, world cities, globalization, advanced producer services, multidimensional scaling 
It is nearly a decade since O'Brien (1992) famously proclaimed 'the end of geography'. Writing about the transnational integration of financial markets, he argued that instantaneous communications have meant distance no longer features as a factor in financial transactions and therefore geography is being eliminated as an impediment to creating this global market. Not surprisingly geographers have responded to this and similar claims with critical analyses of 'borderless world' discourses (e.g. Massey, 1999; Ó Tuathail, 2000) and counter arguments that globalization does not mean the demise of geography (e.g. Corbridge, Thrift and Martin, 1994; Cox, 1997; Yeung, 1998; Taylor, Watts and Johnston, 2001). The gist of these replies is that new communications may destroy some geographies but in their turn they create other new geographies. In the modern world there is always a continual movement of destruction and renewal of spaces and globalization is its latest manifestation. Thus, while many aspects of global finance have become virtual, there has also been an enhanced concentration of activities in a few international financial centres resulting in another geography based upon the likes of London, New York and Tokyo. Hence, rather than the end of geography there are exciting new geographies being produced under conditions of contemporary globalization. The purpose of this paper is to present a new mapping of the world that captures the key features of one, very important, global geography. This is an empirical contribution to illustrate the counterarguments to the 'end of geography' thesis.

The new mapping of the world focuses on cities rather than states. It is based upon Castells' (1996) conceptualization of the contemporary world as a network society wherein 'spaces of flows' are coming to dominate 'spaces of places'. The latter space is defined by separation and boundaries, the former by interaction and connections. For instance, the familiar world political map of sovereign boundaries is the way in which the space of places has been portrayed at the world scale. With globalization, however, transnational processes are leading to the erosion of the efficacy of these state boundaries. The network society consists of a myriad of flows at many different scales including transnational movements which have created global networks. The world city network is the most discernible expression of the latter. Hence world cities are the focus of the new world mapping that will be derived from connections between cities across the world. These connections are surrogate measures for inter-city flows of economic information so that the end result is a new representation of a global economic space of flows to complement the traditional representation of an international political space of 
places. It is important to note the thesis is not about replacement of the political map but rather that on its own that map no longer provides an adequate spatial framework for understanding social change under conditions of contemporary globalization: hence the need for a new mapping of the world.

The argument proceeds in five stages. First, world cities are interpreted as global service centres where advanced business services are provided for multinational corporations. New communication and computing technologies have enabled some firms in sectors such as accountancy and law to expand their services beyond their traditional single city or national markets. These are the agents of change at the centre of interest here. Unfortunately, because they are private institutions, there is a dearth of publiclyaccessible data on their activities. In the second section, this question of data deficiency is discussed leading to section three where the collection of data for this project is described. This consists of information about the offices of 46 business service firms in 55 world cities. From this data a 55 x 55 inter-city matrix of connections is derived as input to a multidimensional scaling analysis which is described in section four. In the fifth section, the 'global service space' produced by this technique is described and interpreted. This is the new mapping of the world which reveals an interweaving of hierarchy and region in a city-based global space of flows.

\section{The rise of global service cities}

The merging of communication and computer technologies in the 1970s provided the potential for the spatial dispersion of many social and economic activities. Properly equipped, a business in the Isle of Skye can be as well connected electronically as any of its counterparts in London. Given such problems as the high rents and commuting difficulties in large urban agglomerations, it might be thought that advances in telecommunications would make cities obsolescent. In fact, quite the opposite has occurred (Sassen, 1994). Instead of declining, large cities such as London have prospered in the era of instantaneous communications across the globe. This prosperity has been built upon a boom as many major firms - foremost users of these communications - choose to locate in the world's leading cities. 
Several explanations have been put forward for this renewed concentration of business in what have come to be known as world or global cities (Friedmann, 1986; Sassen, 1991; Storper, 1997; Thrift, 1996). The new communication technologies deal in information and knowledge. It is the former which is transmitted through telecommunications so that there is the potential for equality of information across the world. But what matters in business is the capacity to use information productively. It is this capacity which remains highly unevenly distributed. Cities are the places where information is transformed into productive knowledge. This knowledge is produced continually in cities through face-to-face contacts and networking, to gain the expertise necessary to understand the significance of information received. Recruits to a firm may be sent to different cities in their early careers in order to gain a wide 'culture of expertise'. There is no better example of this than in banking and finance. The institution of a globally-integrated financial market has been accompanied by the rise of great international financial centres such as London, New York and Tokyo. These are places where innovative new financial instruments are locally produced for the global market (Thrift, 1996). World cities, therefore, can be interpreted as particularly knowledge-rich environments within a myriad of global information networks.

Not all large firms have been investing in new offices in world cities. There is, for example, evidence that non-service multinational corporations have been disinvesting in offices in the larger cities (Lyons and Salmon, 1995). The firms which have most to gain from knowledge-rich locations are corporate service firms which are engaged globally in accounting, advertising, law, insurance, and various consultancies as well as banking/finance. Traditionally located in cities to service locally, these firms were initially forced to 'go global' to follow, and thus keep, their multinational corporate clients. Subsequently, many of the most successful service firms have developed their own global strategies to provide a 'seamless' service across the world to attract new multinational corporate clients. It is these service firms with their professional practitioners combining their basic 'certified knowledge' with city-corporate-experience knowledge who need to be at the heart of world cities. Hence international financial centres such as London have turned into more general global service cities in the last two decades, each providing a large menu of global services in an inter-connected network of world cities (Taylor, 2001). Global service cities are the subject matter of the rest of this paper. 


\section{The dearth of evidence}

There has been a basic problem in studying cities in the world economy: data on relations between cities are not readily obtainable (Short et al., 1996; Taylor, 1997; Taylor, 1999). Most global-urban research has focused upon the populations of cities across the world reflecting the availability of such data from national censuses (and reproduced in UN publications). But even in demography, there are little or no data on flows of people between cities either permanently or short-term. Once research moves beyond people to their activities, availability of relevant data on cities and their relations declines dramatically. Economic transactions such as foreign direct investments which are of key interest to understanding world cities (Sassen, 1994) are only available for countries; investment in Sydney cannot be separated from investment in Melbourne.

The reason for this dearth of evidence on connections between world cities is that 'official statistics' are collected by states and are therefore, quite naturally, about states (Taylor, 1996). These data are suitable for studying international relations or any analysis where states are deemed to be the prime units (e.g. development studies) but they are much less relevant to research which focuses on trans-state processes. Servicing multinational corporations globally is just such a bundle of processes. In short, using official statistics forces any global analysis to use the 'old world map' of states, a world 'space of places' already rejected for this study.

The only alternative is to search out new evidence. The problem which then arises is that this leads inevitably to private sector sources where commercial sensitivity becomes a critical issue. For instance, data are available for passenger traffic between city airports but such gross figures do not distinguish between business travel and other travel such as tourism. In a world-wide study of inter-city routes, for example, New York-Miami comes first for the number of flights per week suggesting much more than the business link (Keeling, 1995: Table 7.4, 126). Data on business travel between cities would be a valuable indicator, but given the profitability of Business Class travel in a highly competitive market, it is no surprise that airlines are not willing to make such data publicly available. There is no solution to the dearth of evidence down this route: searching for such economic flows between cities at a global scale soon turns out to be a statistical chimera. A different tack is required. Instead of trying to measure a space of 
flows it is sensible to reign in ambition and consider a space of connections. The latter will go beyond the simple infrastructure links as available for travel. Corporate connections can be derived from the spatial organizational structures of companies. Such connections not only imply flows but their crucial property is that they are more easily available in a specific form which can be used to measure relations between world cities. This is a solution to the dearth of evidence.

\section{Global service strategies}

One of the 'selling' features of large service firms to prospective new clients or to new professional recruits is their global reach. The very opposite to commercial secrecy, firms proclaim their ability to provide a service across the world in all their publicity material. This normally takes the form of a network of offices. There are several other ways in which a firm can provide a service to a client across the world, such as having alliances with partner firms in different countries, but none matches the seamless service with control on quality which an 'in-house' office network can provide. Hence the big service firms have invested heavily in having offices in the leading cities of the world. The distribution of the offices of a given firm across cities reveals the global service strategy of that firm.

Data have been collected on 46 global service firms in accountancy, advertising, banking/finance and law (Taylor and Walker, 2001). To qualify as 'global' in this study, firms have to have offices in at least 15 different cities. Offices were graded by importance in the firm using size (e.g. number of practitioners) or function (e.g. regional headquarters) to create an ordinal measure of each firm in a city: 3 indicates important presence, 2 medium presence, 1 low presence and 0 no presence. These measures were recorded for 55 world cities defined in a previous study (Beaverstock et al., 1999). The result is a 46 firm x 55 city data matrix of the location strategies of global service firms.

Connectivity between cities can be derived from this matrix in the following way (Taylor, 2001). For any pair of cities the product of their scores for any firm is computed. The sum of the cross products for all 46 firms for that pair of cities reflects the similarity between the two cities in terms of global service strategies. It is a 
surrogate for particular flows of information and knowledge between the cities if the following assumptions are made:

1 offices generate more flows within a firm's network than to other firms in the sector. This has not yet been empirically tested but is inherently plausible. For instance, drawing up an inter-jurisdictional contract by a law firm will involve flows of information and knowledge between offices of that firm to achieve the ideal seamless service.

2 the larger the office, the more flows are generated and these have a multiplicative effect on inter-city relations. The first part of this assumption is obviously very plausible again. The second part reflects the hierarchical nature of office networks where larger offices have special functions like control and provision of specialized knowledge. Without evidence of actual flows there is no easy means of estimating this effect, a multiplicative process is a reasonably simple way to reflect the importance of major offices in the world city network. The end result is a $55 \times 55$ inter-city matrix of connections based upon global service strategies.

\section{Defining a global service space}

The first step in defining a space is to create a distance matrix. This requires each intercity connection in the connectivity matrix to be expressed as a proportion of the maximum level possible with this data. For 11 firms only presence/absence information was available, so that the maximum score for any pair of cities is $11+\left(3^{2} \times 35\right)=326$. Subtracting each proportionate connection from unity produces what may be termed 'global service distances' between cities: the smaller the measure, the closer are the two cities in terms of their corporate service mixes. 'Self-distances' - the distance of a city from itself - are defined as zero. The result is a 55 x 55 city distances matrix representing network proximity rather than the more familiar territorial proximity (Jönsson et al., 2000, 102). It is from this matrix that a global service space can be created. 
Multidimensional scaling (MDS) is the standard technique for defining spaces from a matrix of distances (or dissimilarities) between objects (Kruskal and Wish, 1978; Young, 1987). Computationally, the technique involves an iterative process that converges towards a spatial configuration of the objects that minimizes a measure of 'stress' (badness-of-fit comparing distances between objects in the new configuration and in the original matrix). Such configurations can be produced to create best-fit spaces of any dimension up to the size of the matrix. Obviously higher dimensions cannot be depicted diagrammatically and therefore it is usually hoped that two- or threedimensional solutions provide good descriptions of the data (Cliff et al., 1995). In Geography, one of the early applications of MDS to inter-city data was made by Forer (1978) who created 'airline travel-time' two-dimensional spaces as 'plastic maps' of the Pacific region. Following his early lead, a two-dimensional configuration has been produced from the corporate services distance matrix, using the MDS procedure of the statistical package SAS/STAT (SAS Institute Inc. 1996, 493-530). As far as we are aware, this mapping is the first application of the technique on a global (city) scale. In this case Kruskal's stress formula 1 yields a badness-of-fit criterion of 0.275 for the two-dimensional solution compared to 0.198 for three dimensions. Visualization experiments with both two and three dimensions have shown that the ease of depiction with the former more than compensates for goodness-of-fit lost through reducing by one dimension.

The two-dimensional solution is shown in Figure 1; this forms the basis of the new mapping of network proximity being generated here. The first thing to notice about this global service space is that it has a highly centric distribution of cities. Global service centres are arrayed in a basic core-periphery pattern with a small number of cities at the centre and a decline in density towards the outer rim. This is a new mapping in need of exploration.

\section{Hierarchical tendencies and regional order}

In the original definition of world cities three status levels were identified (Beaverstock et al., 1999): 10 alpha world cities, 10 beta world cities and 35 gamma world cities. These are depicted in the new mapping with all cities named (Figure 2). It is 
immediately apparent that the centric pattern is directly related to city status, coreperiphery in this space represents the hierarchical tendency in global service provision. The cluster at the centre includes the five alpha cities normally identified as the leading world cities: London, New York, Tokyo, Paris and Hong Kong. The two alpha cities furthest from the centre are the other US cities Los Angeles and Chicago. This reflects what is sometimes termed the New York 'shadow effect' where many firms service the US market from New York and require no other offices (Beaverstock et al., 2000). In contrast eight beta cities are more centric than these two alpha cities, the most centric are Sydney, Madrid, Toronto and Brussels. This group of beta cities also includes San Francisco which appears better located in global service space than either Los Angeles or Chicago. Moscow is the most eccentric beta city, this is discussed further below. Most of the gamma cities are scattered widely away from the centre although four are notably centric: Amsterdam and Melbourne (both beyond Toronto in Figure 2) and Jakarta and Taipei (near Singapore and Seoul respectively). In contrast, the most eccentric city by far is Minneapolis (in the south-east quadrant) which is the world city with the least service provision.

As well as the hierarchical order there is also a regional order to the global space. A simple quadrant-like division from the core cluster of cities divides the 55 cities into three basic geographical zones: 1 Europe (which itself is divisible into three subzones), 2 USA, and 3 Pacific Asia (Figure 3). There are ten cities which do not belong to any of these three regions (five from Latin America, two each from Canada and Australia, and one from Africa) which are also marked and are discussed further below. Of the remaining 45, there are only four outliers: Moscow, Istanbul, Osaka and Kuala Lumpur. The first two are both unusual examples of Eastern European cities: whereas Budapest, Prague and Warsaw are from ex-COMECON states which are on a pathway to joining the European Union, this is not the case for Moscow (Russia is not joining the EU) or Istanbul (Turkey was never a member of COMECON). Osaka is Japan's second world city of which more below, and Kuala Lumpur is a particularly state-generated world city (Sirat and Ghazal, 1999). All that can be said about these cities is that they cannot be accommodated within a two-dimensional global service space. However, it is testimony to the strength of the regional order within the space that there are only four outliers: 41 out of 45 cities have a pattern of relationships that closely reflects their geographical locations. 
The regionality is actually more subtle than the zonal pattern shows. In Figure 4 regional clusters of cities are identified. Three major regions are shown, based on the original zones except that Europe is splintered with all but six cities allocated to a general 'Western Europe' regional cluster. The cities from outside these regions form distinctive patterns. Australian and Canadian cities form two oblong clusters on the USA side of Western Europe; Latin American cities form two oblong clusters, one in the Europe zone and one between USA and Pacific Asia. This division of Latin American cities reflects NAFTA membership: it is Mexico City and Santiago in the latter cluster lying between New York and Miami; the other cluster of Sao Paulo, Caracas and Buenos Aires is more Atlantic-European in orientation and lies between Madrid and Barcelona.

The oblongs in Figure 4 represent the interweaving of region and hierarchy: they tend to follow axes from centre to periphery. In the case of the Latin American oblongs, the two beta cities (Sao Paulo and Mexico City) are relatively central with other cities out towards their respective peripheries (i.e. moving down the city hierarchy). Australia and Canada are two examples of the five countries which have two world cities located within them (Taylor, 2000: Table 3, 17). The Australian and Canadian oblongs represent their prime world city (Sydney and Toronto respectively) near the centre with the other world cities out towards the periphery. There are three European duo-world city countries (Italy, Spain and Switzerland) and each features a hierarchical separation: Rome is on a trajectory out from Milan near the centre, and Barcelona and Geneva have similar relations to Madrid and Zurich respectively. The other country with a pair of world cities is Japan, one is central (Tokyo), the other peripheral (Osaka) but they do not have an 'Asian' orientation since Osaka is an outlier (Figure 3). Finally, the Eastern European oblong has no such core-periphery trajectory since it does not have a prime city near the centre of global service space: Moscow is the only candidate and it has had a much less European incorporation into the world market than Prague, Budapest and Warsaw since the end of the Cold War.

It should be noted that the three main regions express this same interweaving of hierarchy and region (Taylor and Walker, 2001; Taylor and Hoyler, 2000; Taylor et al., 2000). In each case their regional space in Figure 4 comes to a peninsula at the centre. 
The peninsulas are shown in more detail in Figure 5 where the separation of the prime world cities in each region is precise with each city in its correct 'real' relative location.

Figure 4 is offered as a first new mapping of the world under conditions of contemporary globalization. To be sure, there have been depictions of the distributions of new infrastructures that facilitate globalization (see, for instance, Dodge and Kitchin, 2000) but the global service space produced here manifests connections at the social network level of Castells' network society, the level where human activities are directly creating a globalizing world. The production of the new space of hierarchy and region has combined statistically robust analysis of empirical data with plausibility in terms of contemporary knowledge of global economic geography. It is a new mapping of the new millennium's space of flows.

\section{The meaning of the new mapping of the world}

The initial stimulus to this mapping exercise was to provide an empirical geographical answer to the 'end of geography' thesis. The global service space meets this requirement but it points to additional questions and interpretations. Two particular issues are raised here by way of a conclusion looking forward to further research.

First, the analysis informs thinking on the nature of spaces. Although firmly embedded in a space of flows argument, the results reintroduce spaces of places. There are 'continental' places explicitly revealed as the regionality of the new space and, more subtly, the state appears in the way lower order cities from a country are in the 'shadow' of their country's prime world city. Clearly, in any geographical study, spaces of flows and spaces of places can never be separated: they are necessarily intertwined, each space relies on the other for its reproduction. Additionally, these places define distinct geographical scales and the analysis therefore illustrates also the interplay of different levels of social action. Above the state and regional levels, the global seems to be overtly represented as urban hierarchy expressed as a highly centric space. What this shows is that globalization is a rescaling of human activities to be sure, but it is not a simple imposition of one scale on other scales. Any new geography mixes adaptations 
of old spaces with inventions of new spaces in the continual evolution of the complex spaces of modernity.

Second, the analysis leads to consideration of how the world city network relates to other global spatial frameworks, notably the core-periphery pattern of the world economy. The core-periphery model as propounded by world-systems analysts (Wallerstein, 1979) is created by a space of flows defined by commodity chains, goods and services moving up a production process until capital is realized in the final act of consumption. The world city space of flows relates to the services used for organization of these commodity chains by provision of business services from a bank's initial lending of capital to begin the chain through to use of an advertising agency's services to facilitate the final consumption. But there is another interpretation that dispenses with the distinction between services and production. World cities can be viewed as advanced production sites where the output is in the form of sophisticated knowledge products (Sassen, 1991). The service firms in this study are large multinational corporations in their own right. They represent an important cutting edge industry in the contemporary world economy, a locus for large-scale profits. Hence they can be interpreted as key core-producing agents. Viewed this way, the activities of global service firms are confirming the core-periphery pattern across the world but with important influences beyond the traditional core where they are motors of semiperipheral growth. The semi-periphery is defined as a mix of core and peripheral processes, here it is represented where there is a clustering of core processes in world cities amidst a peripheral local hinterland. Whether world cities can be part of a transformation to core status is still to be determined in Pacific Asia (beyond Japan) in the early decades of the millennium. However, elsewhere in the 'third world', world cities are too sparse to have any major influence. The cities in this analysis, selected by their prowess in business service provision, are predominantly from the 'first world'. Thus, with business services as a cutting edge industry, the new mapping with its centric structure not only confirms the core-periphery pattern but suggests further that it is taking a particularly intensive and selective form, an accentuation of geographical polarization, under conditions of contemporary globalization. 


\section{Acknowledgements}

We acknowledge the support of two projects by the ESRC for the research upon which this paper is derived: 'The geographical scope of London as a world city: a relational study' (R000222050) and 'World city network formation in a space of flows' (R000223210). We thank Richard Smith and Jon Beaverstock for their contributions to the first-named project. Funding from the Faculty of Social Sciences and Humanities (Loughborough University) for Michael Hoyler to spend time as a research associate in Loughborough is also acknowledged. We thank Oliver Kögler (Heidelberg) for his assistance with the statistical analysis.

All data are available at the Globalization and World Cities (GaWC) Study Group and Network web site: http://www.lboro.ac.uk/gawc/ 


\section{References}

Beaverstock, J.V., Smith, R.G. and Taylor, P.J. 1999 A roster of world cities. Cities 16: 445-58.

Beaverstock, J.V., Smith, R.G. and Taylor, P.J. 2000 World city network: a new metageography? Annals of the Association of American Geographers 90: 123-34.

Castells, M. 1996 The rise of the network society. Oxford: Blackwell.

Cliff, A.D., Haggett, P., Smallman-Raynor, M.R., Stroup, D.F. and Williamson, G.D. 1995 The application of multidimensional scaling methods to epidemiological data. Statistical Methods in Medical Research 4: 102-23.

Corbridge, S., Thrift, N. and Martin, R. (eds.) 1994 Money, power and space. Oxford: Blackwell.

Cox, K.R. (ed.) 1997 Spaces of globalization: reasserting the power of the local. New York: Guilford Press.

Dodge, M. and Kitchin, R. 2000 Mapping cyberspace. London: Routledge.

Forer, P. 1978 A place for plastic space? Progress in Human Geography 2: 230-67.

Friedmann, J. 1986 The world city hypothesis. Development and Change 17: 69-83.

Jönsson, C., Tägil, S. and Törnqvist, G. 2000 Organizing European space. London: Sage.

Keeling, D.J. 1995 Transport and the world city paradigm. In Knox, P.L. and Taylor, P.J. (eds.) World cities in a world-system. Cambridge: Cambridge University Press: 115-31.

Kruskal, J.B. and Wish, M. 1978 Multidimensional scaling. Beverly Hills: Sage. 
Lyons, D. and Salmon, S. 1995 World cities, multinational corporations, and urban hierarchy: the case of the United States. In Knox, P.L. and Taylor, P.J. (eds.) World cities in a world-system. Cambridge: Cambridge University Press: 98-114.

Massey, D. 1999 Imagining globalization: power-geometries of time-space. In Brah, A., Hickman, M. and Mac an Ghaill, M. (eds.) Global futures: migration, environment and globalization. Basingstoke: Macmillan: 27-44.

O'Brien, R. 1992 Global financial integration: the end of geography. London: Pinter.

Ó Tuathail, G. 2000 Borderless worlds? Problematizing discourses of deterritorialization in global finance and digital culture. Geopolitics 4: 139-54.

SAS Institute Inc. 1996 SAS/STAT software: changes and enhancements through release 6.11. Cary, NC: SAS Institute Inc.

Sassen, S. 1991 The global city. Princeton, NJ: Princeton University Press.

Sassen, S. 1994 Cities in a world economy. Thousand Oaks, CA: Pine Forge Press.

Short, J., Kim, Y., Kuss, M. and Wells, H. 1996 The dirty little secret of world cities research. International Journal of Urban and Regional Research 20: 697-717.

Sirat, M. and Ghazal, S. 1999 Globalization of economic activities and Third World cities: a case study of Kuala Lumpur. Kuala Lumpur: Utusan.

Storper, M. 1997 The regional world. New York: Guilford.

Taylor, P.J. 1996 Embedded statism and the social sciences: opening up to new spaces. Environment and Planning A 28: 1917-28.

Taylor, P.J. 1997 Hierarchical tendencies amongst world cities. Cities 14: 323-32. 
Taylor, P.J. 1999 "So-called world cities": the evidential structure within a literature. Environ and Planning A 31: 1901-04.

Taylor, P.J. 2000 World cities and territorial states under conditions of contemporary globalization. Poitical Geography 19: 5-32.

Taylor, P.J. 2001 Specification of the world city network. Geographical Analysis 33: 181-94.

Taylor, P.J., Doel, M.A., Hoyler, M., Walker, D.R.F. and Beaverstock, J.V. 2000 World cities in the Pacific Rim: a new global test of regional coherence. Singapore Journal of Tropical Geography 21: 233-45.

Taylor, P.J. and Hoyler, M. 2000 The spatial order of European cities under conditions of contemporary globalization. Tijdschrift voor Economische en Sociale Geografie 91: 176-89.

Taylor, P.J. and Walker, D.R.F. 2001 World cities: a first multivariate analysis of their service complexes. Urban Studies 38: 23-47.

Taylor, P.J., Watts, M.J. and Johnston, R.J. 2001 Geography/globalization. In Johnston, R.J., Taylor, P.J. and Watts, M.J. (eds.) Geographies of global change. Second edition. Oxford: Blackwell (in press).

Thrift, N. 1996 Spatial formations. London: Sage.

Wallerstein, I. 1979 The capitalist world-economy. Cambridge: Cambridge University Press.

Yeung, H. W-c. 1998 Capital, state and space: contesting the borderless world. Transactions of the Institute of British Geographers 23: 291-309.

Young, F.W. 1987 Multidimensional scaling: history, theory, and applications. Hillsdale, NJ: Lawrence Erlbaum Associates. 
Figure 1 The distribution of world cities in global service space

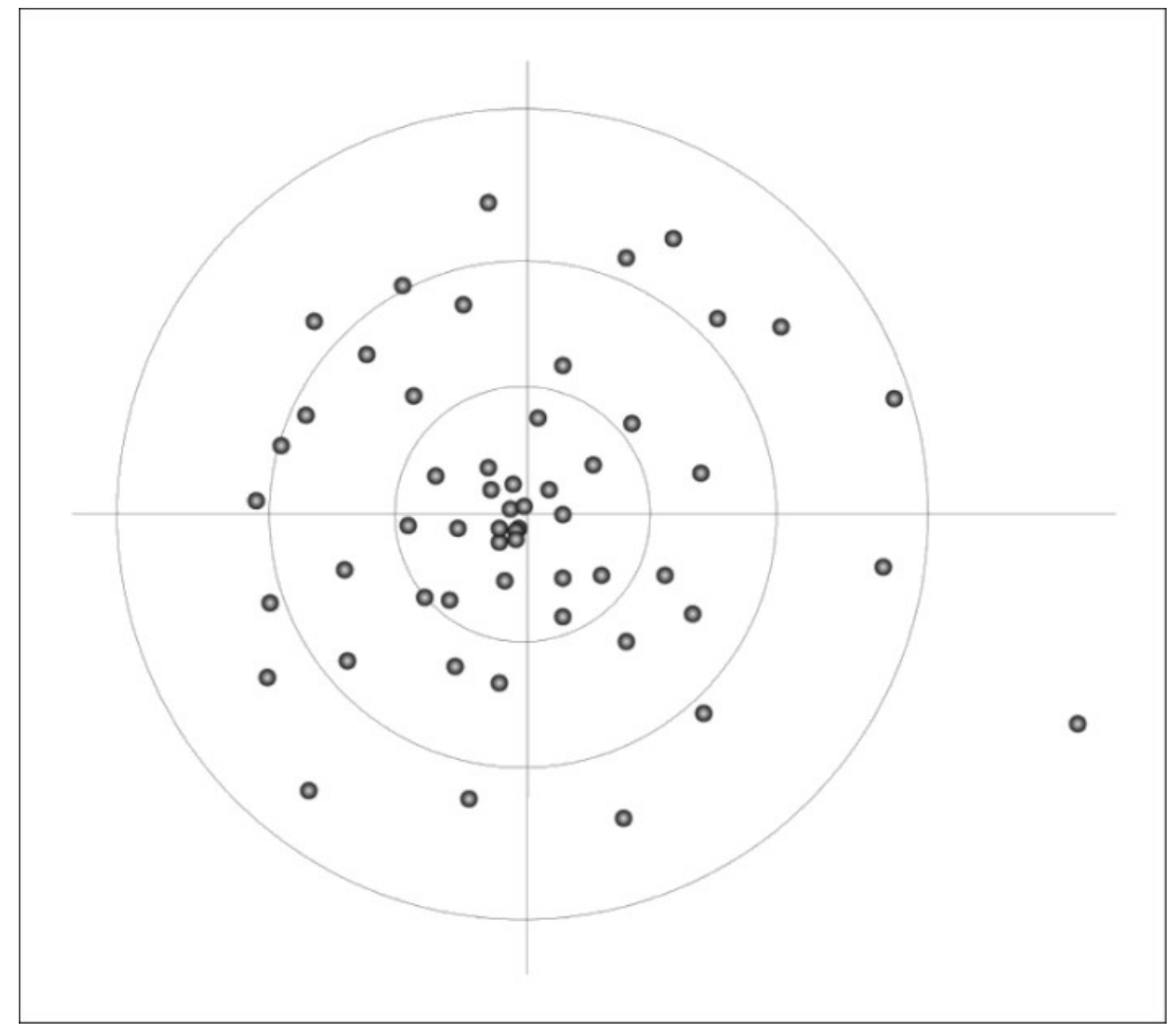


Figure 2 Hierarchical tendencies in global service space

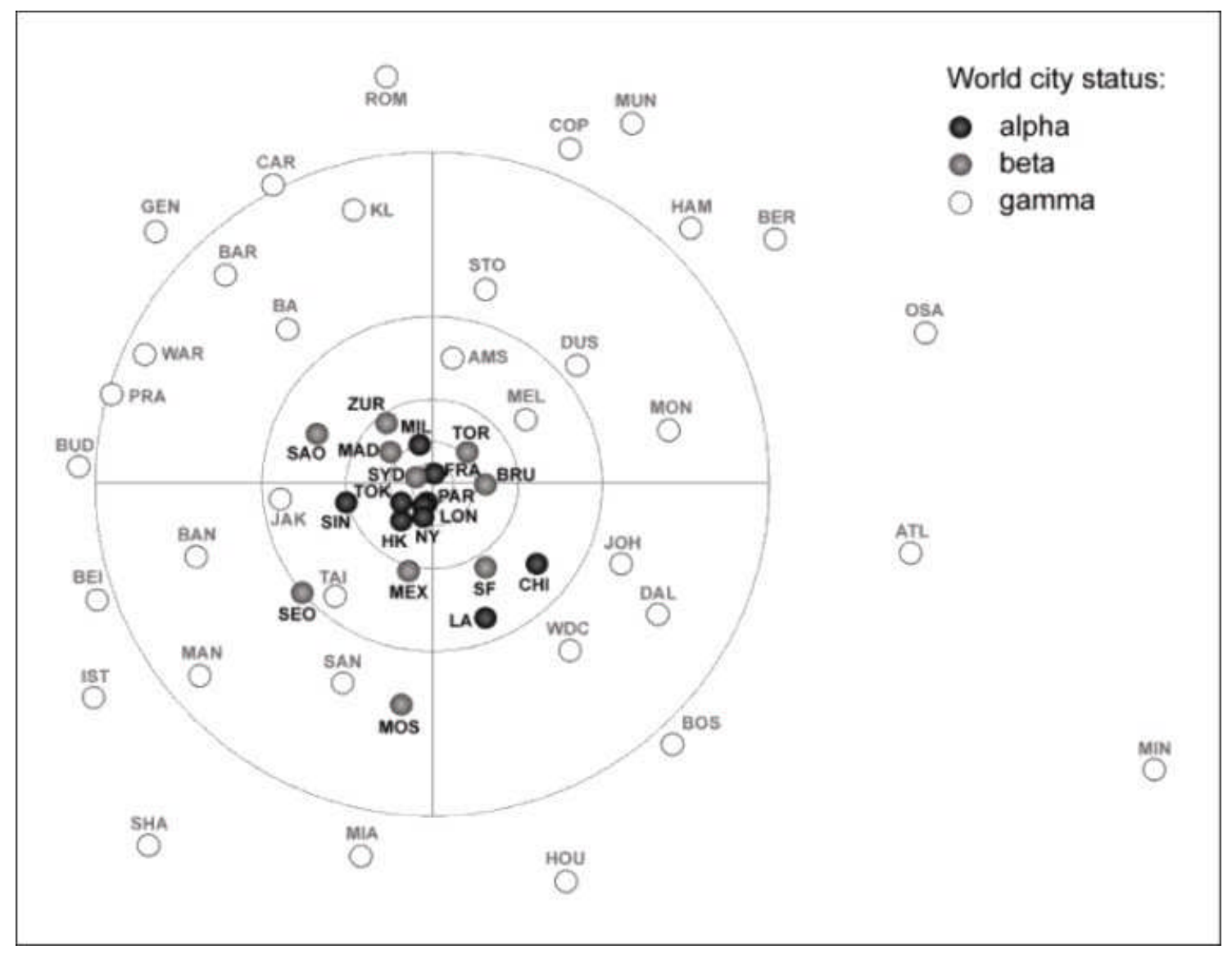

Alpha world cities: Chicago (CHI), Frankfurt (FRA), Hong Kong (HK), London (LON), Los Angeles (LA), Milan (MIL), New York (NY), Paris (PAR), Singapore (SIN), Tokyo (TOK).

Beta world cities: Brussels (BRU), Madrid (MAD), Mexico City (MEX), Moscow (MOS), San Francisco (SF), Sao Paulo (SAO), Seoul (SEO), Sydney (SYD), Toronto (TOR), Zurich (ZUR).

Gamma world cities: Amsterdam (AMS), Atlanta (ATL), Bangkok (BAN), Barcelona (BAR), Beijing (BEI), Berlin (BER), Boston (BOS), Budapest (BUD), Buenos Aires (BA), Caracas (CAR), Copenhagen (COP), Dallas (DAL), Düsseldorf (DUS), Geneva (GEN), Hamburg (HAM), Houston (HOU), Istanbul (IST), Jakarta (JAK), Johannesburg (JOH), Kuala Lumpur (KL), Manila (MAN), Melbourne (MEL), Miami (MIA), Minneapolis (MIN), Montreal (MON), Munich (MUN), Osaka (OSA), Prague (PRA), Rome (ROM), Santiago (SAN), Shanghai (SHA), Stockholm (STO), Taipei (TAI), Washington (WDC), Warsaw (WAR). 
Figure 3 Zonal divisions in global service space

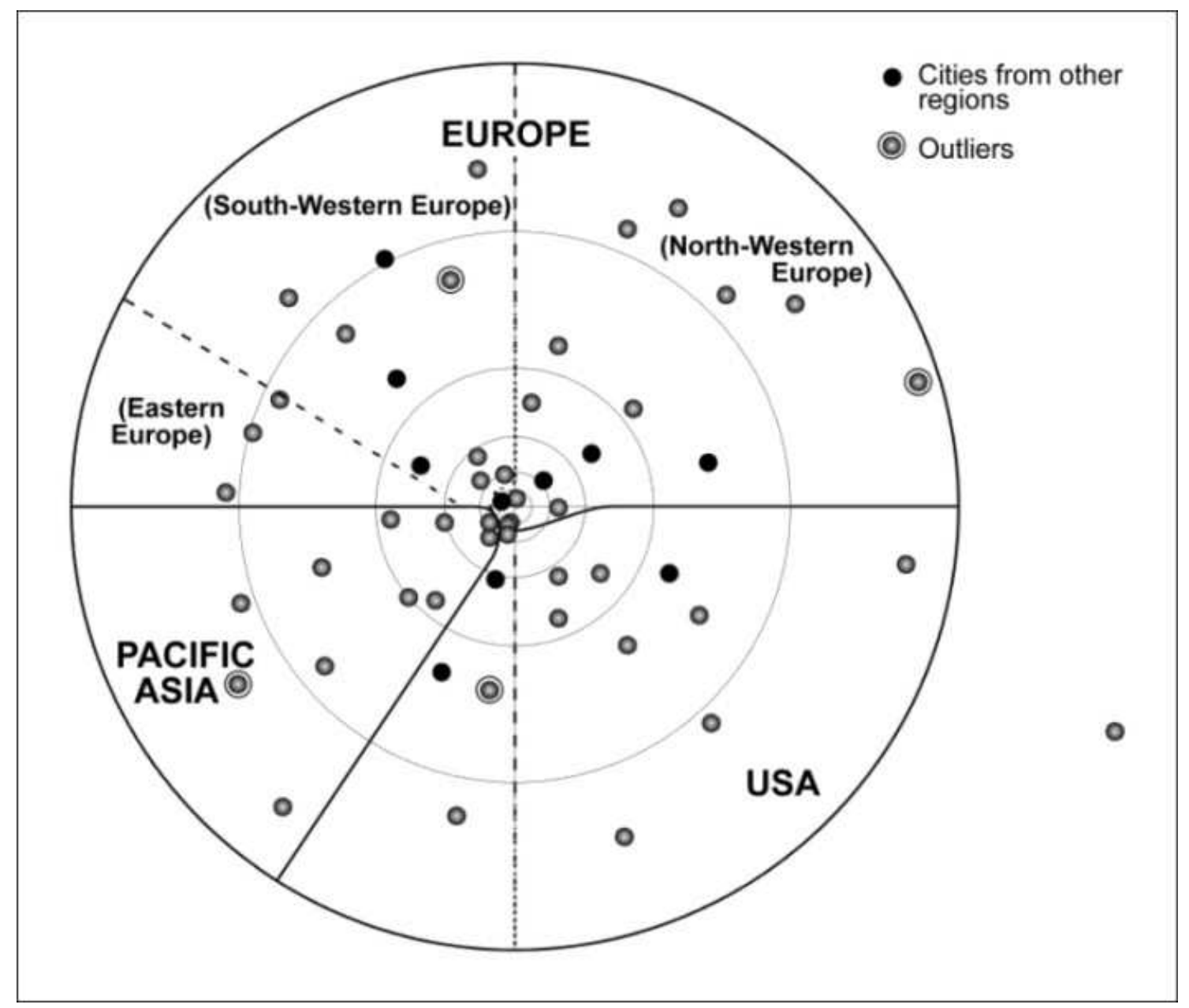


Figure 4 Regional tendencies in global service space

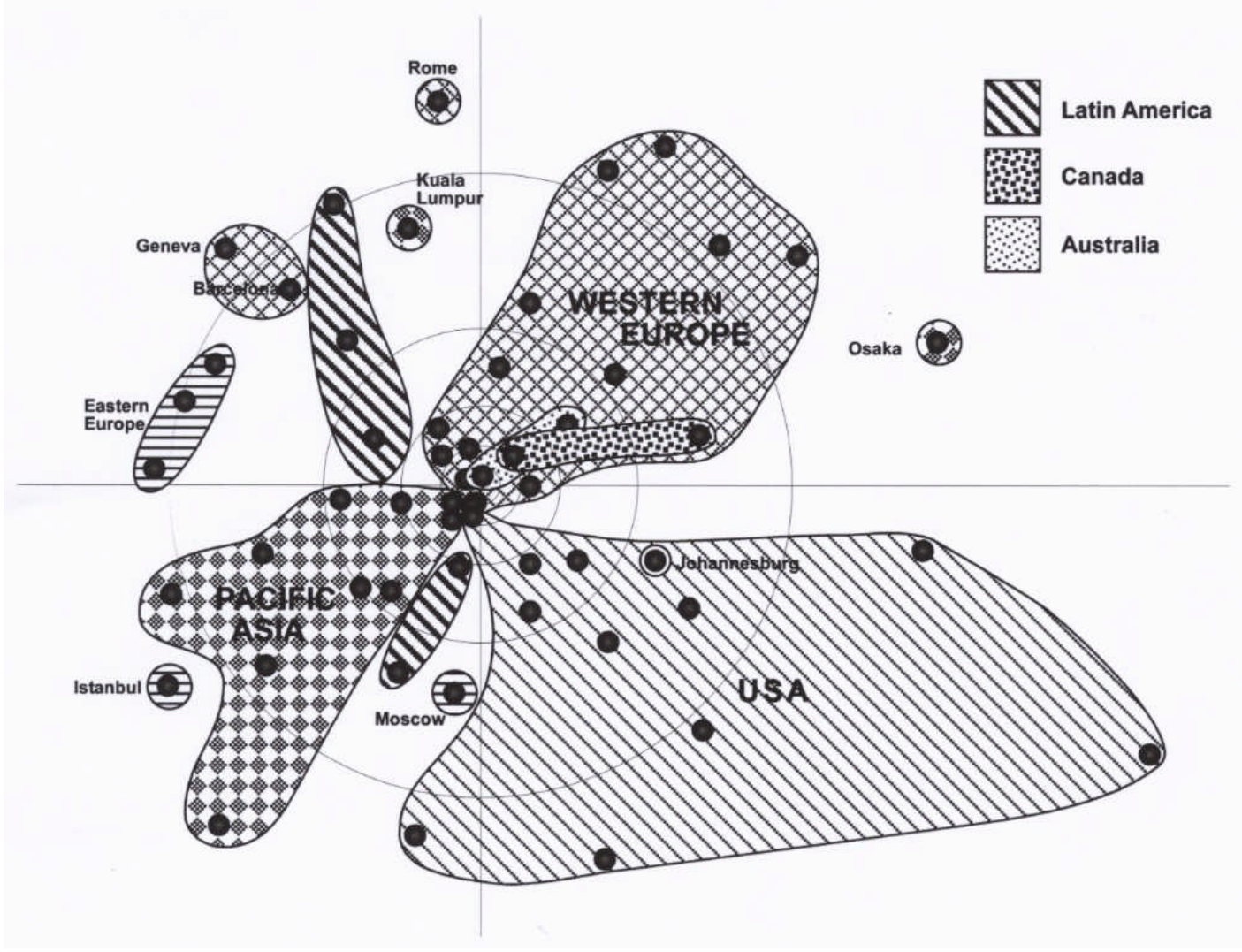


Figure 5 Cities at the centre of global service space

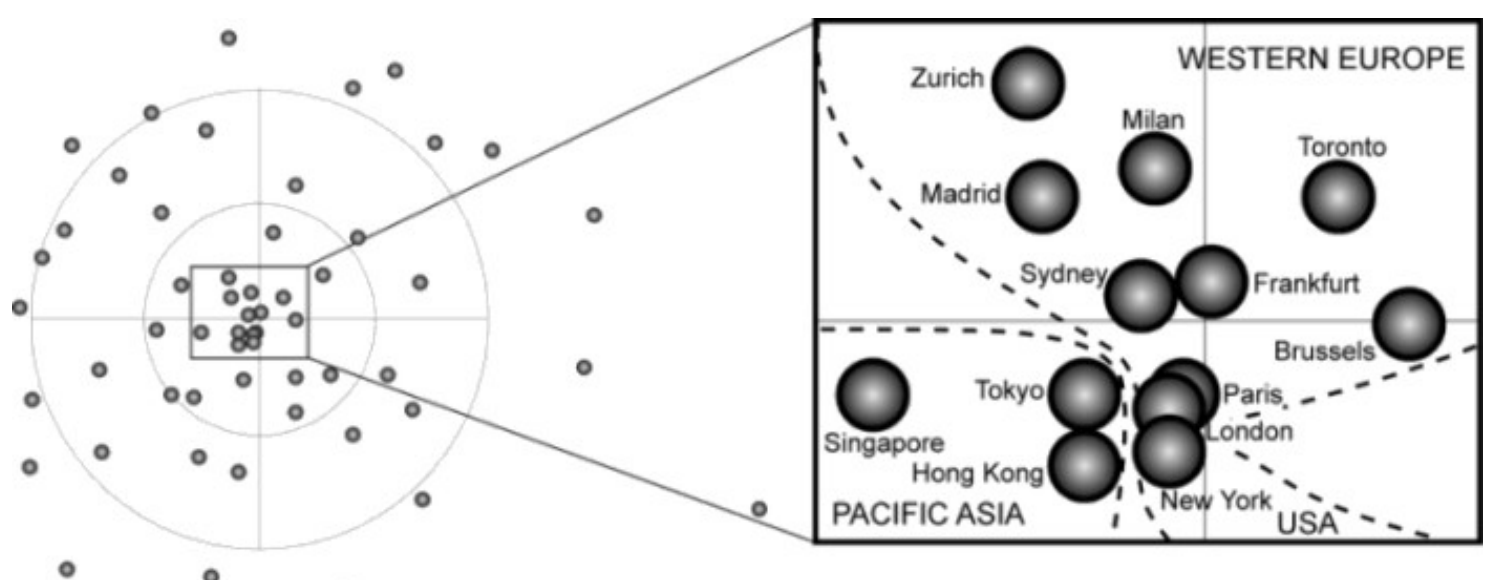

